\title{
FRAKSI ETANOL DAUN LIDAH BUAYA (Aloe vera L.) SEBAGAI ANALGETIKA TERHADAP TIKUS PUTIH JANTAN GALUR WISTAR (Rattus norvegicus)
}

\author{
Ethanol Fraction Leaf Aloe Vera (Aloe Vera L.) \\ Analgesics As Of White Rats Wistar Male \\ (Rattus Norvegicus)
}

\author{
Mashuri Yusuf, Yuli Wahyu Trimulyani, Hestantia Titik Lestari \\ Jurusan Farmasi FMIPA, Universitas Tulang Bawang Lampung \\ E-mail : mashuriyusuf09@gmail.com \\ 081273792722
}

\begin{abstract}
Aloe vera leaf (Aloe vera $L$.) are the medicinal plants that thrive in Indonesia. One of the main ingredients in Aloe vera leaf (Aloe vera $L$.) is a flavonoid that provides a wide range of pharmacological activity and one of them as an analgetic. The aim of this study was to determine the analgeti effect of ethanol fraction Aloe vera leaf (Aloe vera $L$.) on white rats (Rattus norvegicus) thermic induced. The test animals used were 25 rats divided into 5 groups, each group consisting of 5 rats. Group 1 was given $2 \mathrm{ml}$ of CMC 0,5\%, group 2 was given $2 \mathrm{ml}$ of mefenamic acid suspension, while the third group, 4 and 5 were given ethanol fraction Aloe vera leaf a dose of $6.37 \mathrm{mg} / \mathrm{kg} \mathrm{BW}, 12.74 \mathrm{mg} / \mathrm{kg} \mathrm{BW}$, $25.4 \mathrm{mg} / \mathrm{kg}$ BW. Testing the analgesic effect is done by giving pain stimulation to the test animals using heat stimulation at a temperature of $65^{\circ} \mathrm{C}$. The response of the mice observed was the movement of licking legs and or jumping. Observations were carried out for 1 minute before administering the test substance then in the 30 minute after the test material was given until 120 minutes. The data obtained were analyzed using ANOVA test and continued with Duncan's test. The results of the ANOVA test showed that the average response of rats in the dose III group did not differ significantly from the positive control group. The results showed that the ethanol fraction of aloe vera leaves had an analgesic effect on wistar strain male rats. The III dose of $25.4 \mathrm{mg} / \mathrm{kg} \mathrm{BW}$ showed a decrease in analgesic greater than doses I and II.
\end{abstract}

Keywords : Analgetic, aloe vera leaves, rattus norvegicus

\begin{abstract}
Abstrak
Daun lidah buaya (Aloe vera L.) merupakan tanaman obat yang tumbuh subur di Indonesia. Salah satu kandungan utama daun lidah buaya (Aloe vera L.) adalah flavonoid yang memberikan berbagai macam aktivitas farmakologi salah satunya sebagai analgetika. Penelitian ini bertujuan untuk menguji efek analgetika fraksi etanol daun lidah buaya (Aloe vera L.) terhadap tikus putih jantan galur wistar (Rattus norvegicus) yang diinduksi secara termik. Hewan uji yang digunakan adalah 25 ekor tikus putih jantan yang dibagi ke dalam 5 kelompok, masing-masing terdiri dari 5 ekor tikus putih jantan. Kelompok 1 diberikan2 $\mathrm{ml}$ suspensi CMC 0,5\%, kelompok 2 diberikan2
\end{abstract}


$\mathrm{ml}$ suspensi asam mefenamat, sedangkan kelompok 3, 4 dan 5 masing-masing diberikan fraksi etanol daun lidah buaya dengan dosis $6,37 \mathrm{mg} / \mathrm{Kg}$ BB, $12,74 \mathrm{mg} / \mathrm{kg} \mathrm{BB}, 25,4$ $\mathrm{mg} / \mathrm{kg}$ BB. Pengujian efek analgetika dilakukan dengan cara memberikan rangsangan nyeri pada hewan uji menggunakan rangsangan panas pada suhu $65^{\circ} \mathrm{C}$. Respon tikus putih jantan yang diamati yaitu gerakan menjilat kaki dan atau melompat. Pengamatan dilakukan selama 1 menit sebelum pemberian zat uji kemudian berturut-turut pada menit ke-30 setelah pemberian bahan uji sampai menit ke-120. Data yang diperoleh dianalisa dengan menggunakan uji anova dan dilanjutkan uji Duncan. Hasil analisa uji anova menunjukkan rata-rata respon tikus putih jantan pada kelompok dosis III tidak berbeda secara bermakna dengan kelompok kontrol positif. Hasil penelitian menunjukkan bahwa fraksi etanol daun lidah buaya memiliki efek analgetika terhadap tikus putih jantan galur wistar. Dosis III 25,4 mg/Kg BB menunjukkan penurunan analgetika lebih besar dibanding dosis I dan II.

Kata kunci : Analgetika, daun lidah buaya, tikus putih jantan

\section{PENDAHULUAN}

Indonesia merupakan negara yang memiliki banyak keanekaragaman hayati terutama pada tumbuhan dan diantaranya mempunyai potensi sebagai tanaman obat. Indonesia memiliki lebih dari 20.000 jenis tumbuhan obat, namun 1000 jenis tanaman telah terdata dan sekitar 300 jenis yang sudah dimanfaatkan untuk pengobatan tradisional [1]. Salah satu tanaman yang memiliki khasiat sebagai obat adalah lidah buaya (Aloe vera L.). Lidah buaya digunakan sebagai bahan obat sejak beberapa ribu tahun yang lalu untuk mengobati luka bakar, rambut rontok, infeksi kulit, peradangan sinus, dan rasa nyeri pada saluran cerna. Beberapa peneliti terdahulu telah membuktikan bahwa Aloe vera berkhasiat sebagai antiinflamasi, antipiretik, antioksidan, antimikroba, antiseptik, kosmetik dan juga sebagai analgetika atau penghilang nyeri [2,3].

World Health Organization (WHO) merekomendasikan penggunaan obat tradisional termasuk herbal dalam pemeliharaan kesehatan masyarakat, pencegahan dan pengobatan penyakit, terutama untuk penyakit kronis, penyakit degeneratif dan kanker. WHO juga mendukung upaya-upaya dalam peningkatan keamanan dan khasiat dari obat tradisional. Departemen kesehatan juga menganjurkan penggunaan dan pengembangan serta penelitian tanaman yang berkhasiat obat. Tanaman obat selain harganya yang relatif, dapat dijangkau masyarakat, mudah diperoleh dan penggunaannya juga cukup praktis [1]. Penggunaan tumbuhan berkhasiat obat dengan berbagai alasan herbal dijadikan sebagai pilihan utama untuk pengobatan. Sehingga dengan semakin meningkatnya kesadaran tersebut, risetriset ilmiah pun kini semakin banyak diarahkan pada bahan-bahan alami untuk mengetahui keseluruhan efek khasiat yang terkandung dalam tanaman obat tersebut [4]

Analgetika atau obat penghalang nyeri adalah zat-zat yang mengurangi atau menghalau rasa nyeri tanpa menghilangkan kesadaran. Nyeri dapat disebabkan oleh adanya rangsangan mekanis, kimiawi atau fisis (kalor, listrik) yang dapat menimbulkan kerusakan pada jaringan. Rangsangan tersebut dapat memicu pelepasan zat-zat tertentu yang disebut mediator nyeri, antara lain: histamin, bradikidin, leukotrien dan prostaglandin [5]. Sebagian besar penyakit pada tubuh dapat menimbulkan rasa nyeri sehingga nyeri merupakan salah satu alasan utama seseorang datang untuk mencari pertolongan medis [6]. Pada dasarnya nyeri merupakan keadaan yang 
mengganggu dan tidak nyaman bagi penderitanya, namun nyeri dapat digunakan sebagai tanda adanya kerusakan jaringan, diantaranya nyeri kutan yang bersifat membakar dan lambat hilang dengan pembebasan prostaglandin sebagai mediator spesifik untuk nyeri yang berlangsung lama [7].

Penelitian sebelumnya, menyatakan ekstrak etanol dari daun lidah buaya efektif memiliki aktivitas analgetik pada tikus putih jantan dengan pemberian dosis $0,260 \mathrm{~g} / \mathrm{kgBB}$ yang dapat menurunkan respon sebanyak 16 kali selama 120 menit. Daun lidah buaya mengandung acemanan, saponin, sterol, triterpenoid, flavonoida, tanin, dan polifenol. Penelitian ini dibuktikan bahwa ekstrak etanol daun lidah buaya dapat menghambat prostaglandin sehingga memberi efek analgesik yang didukung dengan adanya senyawa flavonoid [3]. Flavonoid yang berperan sebagai analgetik memiliki mekanisme kerja menghambat kerja enzim siklooksigenase dengan cara mengurangi prostaglandin oleh asam arakidonat sehingga mengurangi rasa nyeri. Selain itu flavonoid juga menghambat degranulasi neutrofil sehingga akan menghambat pengeluaran sitokin, radikal bebas, serta enzim yang berperan dalam peradangan [8]. Berdasarkan latar belakang diatas, peneliti tertarik untuk membuktikan apakah fraksi etanol dari daun lidah buaya dapat memiliki aktivitas analgetik pada tikus putih jantan.

\section{METODOLOGI PENELITIAN}

\section{Bahan dan Alat}

Alat yang digunakan adalah Bejana maserasi, hot plat, timbangan analitik, Stopwatch, erlenmeyer, beaker glass, gelas ukur, labu ukur, kaca aquarium, kandang tikus, sonde oral, batang pengaduk, kertas saring, kertas tempel, cawan petri, tabung reaksi, rak tabung reaksi, kawat, corong pisah $250 \mathrm{ml}$, tabung gelap, statif, kapas, rotary evaporator.

Bahan yang telah digunakan dalam penelitian ini meliputi: Daun Lidah Buaya (Aloe vera L.), CMC (Carboxy methyl cellulosse), tablet asam mefenamat $500 \mathrm{mg}$, aquadest, pakan tikus, tikus putih jantan galur wistar (Rattus novergicus), etanol $70 \%, \mathrm{~N}$ heksan p.a $\left(\mathrm{C}_{6} \mathrm{H}_{1}\right)$, kloroform p.a $\left(\mathrm{CHCl}_{3}\right)$, etanol p.a $\left(\mathrm{C}_{2} \mathrm{H}_{5} \mathrm{OH}\right)$, asam klorida pekat (HCL), asam sulfat $\left(\mathrm{H}_{2} \mathrm{SO}_{4}\right)$, besi (III) klorida $\left(\mathrm{FeCl}_{3}\right)$, asam asetat $\left(\mathrm{CH}_{3} \mathrm{COOH}\right)$, serbuk magnesium $(\mathrm{Mg})$, pereaksi Mayer, pereaksi Dragendorff.

\section{PROSEDUR PENELITIAN}

\section{Persiapan Hewan uji}

Hewan uji (tikus) diadaptasikan selama 7 hari dengan tujuan untuk membiasakan terhadap lingkungan yang baru dan mengurangi stes pada tikus yang dapat mempengaruhi metabolisme dan mengganggu penelitian. Tikus dipelihara dalam kandang yang diberi alas sekam dan ditutup dengan kawat. Pada tahap ini tikus diberi air minum dan makan sebanyak 3 kali sehari. Hewan

\section{Pembuatan Simplisia Daun Lidah Buaya}

Bahan baku daun lidah buaya sebanyak $17 \mathrm{~kg}$ yang masih segar dikumpulkan, dibuang bagian yang tidak diperlukan (sortasi basah), dicuci bersih pada air yang mengalir dan ditiriskan. Daun lidah buaya selanjutnya dihilangkan durinya dengan menggunakan pisau dan dipotong-potong secara horizontal kemudian ditimbang dan didapat sebanyak $10 \mathrm{~kg}$, selanjutnya dijemur hingga kering dibawah sinar matahari yang ditutup dengan kain berwarna hitam, sortasi kering, penghalusan, dan didapat simplisia seberat 300 gram. 


\section{Pemeriksaan Karakteristik Simplisia Daun Lidah Buaya}

\section{Kadar Air Simplisia Lidah Buaya}

Daun Lidah Buaya Dimasukkan lebih kurang 10 gram simplisia dan timbang seksama dalam wadah yang telah ditara. Dikeringkan pada suhu $105^{\circ} \mathrm{C}$ selama 5 jam dan ditimbang. Dilanjutkan pengeringan dan timbang pada jarak 1 jam sampai perbedaan antara 2 penimbangan berturut-turut tidak lebih dari $0,25 \%$.

\section{Pembuatan Ekstrak Etanol Daun Lidah Buaya}

simplisia daun lidah buaya sebanyak $300 \mathrm{mg}$ diekstraksi dengan metode maserasi dimana sampel dimasukkan ke dalam wadah gelap yang tertutup baik dan terlindung cahaya lalu ditambahkan etanol $70 \%$ sampai terendam sempurna selama 6 jam pertama sambil sekali-sekali diaduk, Setelah didiamkan selama 24 jam kemudian disaring sehingga didapat filtrat dan ampas, selanjutnya ampas direndam kembali dengan etanol $70 \%$. Proses maserasi terus dilakukan sampai warna pelarut berubah menjadi jernih. Ekstrak etanol yang diperoleh kemudian diuapakan dengan rotary evaporator sehingga diperoleh ekstrak etanol daun Lidah Buaya kental [9].

\section{Pembuatan Fraksi Etanol Daun Lidah Buaya}

Ekstrak kental daun Lidah Buaya yang didapat ditambahkan etanol sebanyak $100 \mathrm{ml}$ dan dimasukkan dalam corong pisah lalu tambahkan $100 \mathrm{ml}$ n-heksan dan dilakukan pengocokkan lalu pisahkan fraksi etanol dan fraksi nheksan, ambil fraksi etanol yang didapat kemudian masukkan kembali kedalam corong pisah dan tambahkan n-heksan yang baru $100 \mathrm{ml}$. Proses ini dilakukan sampai warna n-heksan tidak berubah lagi. Hasil fraksi etanol yang didapat dimasukkan kembali kedalam corong pisah lalu tambahkan $100 \mathrm{ml}$ kloroform, lakukan pengocokkan dan pisahkan fraksi etanol dan fraksi kloroform. Proses ini dilakukan sampai warna kloroform tidak berubah lagi, fraksi etanol yang didapat dievaporator sampai didapat fraksi etanol kental $18 \mathrm{~g}$ [10].

\section{Pembuatan larutan CMC (Carboxy Methyl Cellulose) 0,5\%}

Timbang CMC sebanyak 0,5 g. Masukkan ke dalam lumpang lalu ditambahkan sedikit demi sedikit aquadest yang sudah dipanaskan. Kemudian digerus hingga homogen dan dimasukkan ke dalam labu ukur $100 \mathrm{ml}$ kemudian add aquadest $100 \mathrm{ml}$.

\section{Pembuatan Suspensi Asam Mefenamat}

Asam mefenamat diberikan dalam bentuk suspensi dengan CMC sesuai dengan dosis efektif manusia, yaitu 500 mg, bila di konversikan berdasarkan konversi Paget dan Barnes, yaitu dosis untuk setiap $200 \mathrm{~g}$ tikus adalah 0,018 kali dosis manusia yaitu 500 mg, sehingga dosis yang digunakan adalah $133,5 \mathrm{mg} / \mathrm{kg}$ BB tikus. Timbang asam mefenamat sebanyak 133,5 mg. Masukkan ke dalam lumpang lalu ditambahkan sedikit larutan CMC. Kemudian digerus hingga homogen masukkan kedalam labu ukur, tambahkan larutan CMC ad $25 \mathrm{ml}$.

\section{Uji Aktivitas Analgetik}

Hewan percobaan dikelompokkan ke dalam 5 kelompok dan 5 kali pengulangan yang masing-masing tikus diadaptasikan dengan lingkungan. Kaca aquarium diletakkan diatas hot plate, kemudian hot plate dipanaskan hingga suhu $65^{\circ} \mathrm{C}$. Setelah suhu mencapai 65ํㅡ, tikus dimasukkan ke dalam kaca aquarium tersebut. Setelah tikus didalam kaca aquarium maka responnya diamati, yaitu berupa 
gerakan menjilat kaki dan atau melompat. Pengamatan dilakukan selama 1 menit. Selanjutnya setiap kelompok diberikan bahan uji secara oral.

\section{a. P3 :}

Diberi fraksi etanol daun lidah buaya dosis $25,4 \mathrm{mg} / \mathrm{kgBB}$ secara oral.

b. Kontrol positif :

Sebagai kontrol positif, tikus diberi asam mefenamat dosis $133,5 \mathrm{mg} / \mathrm{kg}$ BB secara oral.

c. P1:

Diberi fraksi etanol daun lidah buaya dosis $6,37 \mathrm{mg} / \mathrm{kg} \mathrm{BB}$ secara oral.

d. P2 :

Diberi fraksi etanol daun lidah buaya dosis $12,74 \mathrm{mg} / \mathrm{kgBB}$ secara oral.

e. Kontrol negatif :

Sebagai kontrol negatif, tikus diberi suspensi CMC 0,5\% secara oral.

Tikus lalu diistirahatkan selama 30 menit, kemudian selanjutnya tiap tikus dimasukkan kedalam kaca aquarium selama 1 menit. Setelah pengamatan 1 menit, tikus lalu dikeluarkan dari kaca aquarium untuk diistirahatkan dan diamati kembali pada menit ke-30 dengan dimasukkanya kembali tikus kedalam kaca aquarium pengamatan dilakukan hingga menit ke-120, dengan interval 30 menit untuk setiap pengamatan.

\section{Analisis Data}

Data yang diperoleh diolah secara statistik menggunakan SPSS untuk mengetahui pengaruh fraksi etanol daun lidah buaya terhadap pengujian analgetika, dimana penurunan respon analgetik di uji homogenitasnya dan uji kenormalannya. Apabila kedua uji dipenuhi maka selanjutnya dilakukan uji ANOVA satu arah untuk melihat ada tidaknya perbedaan bermakna antara kelompok perlakuan dilanjutkan uji lanjut.

\section{HASIL DAN PEMBAHASAN}

\section{Hasil Uji Fitokimia Fraksi etanol daun lidah buaya}

Hasil skrining menunjukkan bahwa fraksi etanol daun lidah buaya mengandung senyawa metabolit sekunder golongan Saponin, Alkaloid, Flavonoid, Fenol.

Tabel 1. Jumlah Lompatan Selama 120 Menit

\begin{tabular}{c|c|c}
\hline \multirow{2}{*}{ Kelompok } & \multicolumn{2}{|c}{ Rata-rata Jumlah Lompatan Selama 120 Menit } \\
\cline { 2 - 3 } & Perlakuan & $\begin{array}{c}\text { Jumlah Lompatan Rata-rata } \pm \\
\text { SD }\end{array}$ \\
\hline P3 & Dosis III $(25,4 \mathrm{mg} / \mathrm{kgBB})$ & $53,6 \pm 1.342^{\mathrm{a}}$ \\
Kontrol positif & Kontrol + (Asam Mefenamat) & $62,2 \pm 1.304^{\mathrm{a}}$ \\
P2 & Dosis II (12,74 mg/kgBB) & $71,4 \pm 1.581^{\mathrm{b}}$ \\
P1 & Dosis I (6,37 mg/kgBB) & $76,6 \pm 1.000^{\mathrm{b}}$ \\
Kontrol negatif & Kontrol - (Suspensi CMC 0,5\%) & $100 \pm 2.915^{\mathrm{c}}$ \\
\hline
\end{tabular}

Pada tabel 1. terlihat bahwa dosis III $(25,4 \mathrm{mg} / \mathrm{kgBB})$ tidak berbeda nyata dengan kontrol positif. Dosis III $(25,4$ $\mathrm{mg} / \mathrm{kgBB}$ ) memiliki efek analgetik yang sama terhadap kontrol positif dan berbeda nyata dengan kontrol negatif (CMC 0,5\%) sehingga memiliki efek yang baik dibandingkan dengan kontrol negatif. Pada dosis II $(12,74 \mathrm{mg} / \mathrm{kgBB})$ tidak berbeda nyata dengan dosis I $(6,37$ $\mathrm{mg} / \mathrm{kgBB})$ sehingga dosis II $(12,74$ $\mathrm{mg} / \mathrm{kgBB}$ ) memiliki efek analgetik yang sama dengan dosis I $(6,37 \mathrm{mg} / \mathrm{kgBB})$ tetapi berbeda nyata dengan kontrol positif sehingga memiliki efek analgetik yang tidak lebih baik dari kontrol positif. Pada kontrol negatif terlihat sangat berbeda nyata dengan semua perlakuan dimana kontrol negatif tidak memiliki efek analgetik. Aktivitas analgetik juga 
erdapat kecenderungan penurunan nilai

tabel 2. jumlah jilatan setiap kelompok terhadap stimulasi panas yang dapat dilihat pada

Tabel 2. Jumlah Jilatan Selama 120 Menit

\begin{tabular}{c|c|c}
\hline \multirow{2}{*}{ Kelompok } & \multicolumn{2}{|c}{ Rata-rata Jumlah Jilatan Selama 120 Menit } \\
\cline { 2 - 3 } P3 & Perlakuan & Jumlah Jilatan Rata-rata \pm SD \\
\hline Kontrol positif & Dosis III (25,4 mg/kgBB) & $14,2 \pm .548^{\mathrm{a}}$ \\
P2 & Dosis II (12,74 mg/kgBB) & $17 \pm 1.304^{\mathrm{a}}$ \\
P1 & Dosis I (6,37 mg/kgBB) & $18 \pm 1.140^{\mathrm{b}}$ \\
Kontrol negatif & Kontrol - (Suspensi CMC 0,5\%) & $20,6 \pm 1.517^{\mathrm{b}}$ \\
\hline
\end{tabular}

Keterangan: Angka-angka pada kolom yang sama diikuti huruf tika atas yang sama (dibelakang simpang baku) tidak berbeda nyata dengan uji lanjut Ducan.

Kontrol negatif : Suspensi CMC 0,5\%

Kontrol positif : Asam mefenamat

P1

P2

: Fraksi etanol daun lidah buaya dosis $6,37 \mathrm{mg} / \mathrm{kg}$

P3

: Fraksi etanol daun lidah buaya dosis $12,74 \mathrm{mg} / \mathrm{kg}$

: Fraksi etanol daun lidah buaya dosis $25,4 \mathrm{mg} / \mathrm{kg}$

terlihat bahwa dosis III $(25,4 \mathrm{mg} / \mathrm{kgBB})$ tidak berbeda nyata dengan kontrol positif. Dosis III $(25,4 \mathrm{mg} / \mathrm{kgBB})$ memiliki efek analgetik yang sama terhadap kontrol positif dan berbeda nyata dengan kontrol negatif (CMC $0,5 \%$ ) sehingga memiliki efek yang baik dibandingkan dengan kontrol negatif. Pada dosis II $(12,74 \mathrm{mg} / \mathrm{kgBB})$ tidak berbeda nyata dengan dosis I $(6,37$ $\mathrm{mg} / \mathrm{kgBB})$ sehingga dosis II $(12,74$ $\mathrm{mg} / \mathrm{kgBB}$ ) memiliki efek analgetik yang sama dengan dosis I $(6,37 \mathrm{mg} / \mathrm{kgBB})$ tetapi berbeda nyata dengan kontrol positif sehingga memiliki efek analgetik yang tidak lebih baik dari kontrol positif. Pada kontrol negatif terlihat sangat berbeda nyata dengan semua perlakuan dimana kontrol negatif tidak memiliki efek analgetik.

Dilihat dari ketiga dosis fraksi daun lidah buaya yang diberikan, penelitian ini membuktikan bahwa secara farmakologis tumbuhan ini memiliki efek analgetika. Fraksi etanol daun lidah buaya memiliki efek analgetika karena adanya kandungan flavonoid. Flavonoid berperan sebagai analgetika, yang mekanisme kerjanya adalah menghambat kerja enzim siklooksigenase, dengan demikian akan mengurangi produksi prostaglandin oleh asam arakidonat sehingga mengurangi nyeri, selain itu flavonoid menghambat degranulasi neutrophil sehingga akan menghambat pengeluaran sitokon, radikal bebas, serta enzim yang berperan dalam peradangan (11).

Penelitian sebelumnya, menyatakan ekstrak etanol daun lidah buaya efektif memiliki aktivitas analgetik pada tikus putih jantan dari pengamatan yang dilakukan pada menit ke-30, 60, 90, dan 120 setelah pemberian bahan uji yang pada setiap kelompok terdiri dari 3 ekor tikus. Hasil pengamatan menunjukan ekstrak daun lidah buaya dengan dosis $0,065 \mathrm{~g} / \mathrm{kgBB}$, dosis $0,130 \mathrm{~g} / \mathrm{kgBB}$, dan dosis $0,260 \mathrm{~g} / \mathrm{kgBB}$ memiliki efek analgetik pada tikus putih jantan terutama pada dosis $0,260 \mathrm{~g} / \mathrm{kgBB}$ dengan rata-rata nilai total respon tikus yaitu sebanyak 5,333 kali (dibulatkan menjadi 5). Pada fraksi etanol daun lidah buaya memiliki efek analgetik pada dosis $25,4 \mathrm{mg} / \mathrm{kgBB}$ dengan rata-rata 
nilai total respon tikus yaitu sebanyak 5 kali, hal ini diduga karena adanya kandungan flavonoid [3].

Jumlah respon nyeri semakin berkurang seiring semakin meningkatnya dosis yang diberikan kepada hewan uji, sehingga menunjukan bahwa kandungan senyawa analgetik dalam fraksi etanol daun lidah buaya pada berbagai konsentrasi mampu menghambat respon nyeri pada tikus, semakin sedikit rata-rata jumlah respon yang diperlihatkan oleh tikus menunjukkan semakin baik efek analgetik pada suatu

\section{KESIMPULAN DAN SARAN}

\section{Kesimpulan}

1. Berdasarkan penelitian yang sudah dilakukan, fraksi etanol daun lidah buaya memiliki aktivitas analgetika pada tikus putih jantan galur wistar.

2. Fraksi etanol daun lidah buaya dosis III (25,4 $\mathrm{mg} / \mathrm{kg} \quad \mathrm{BB})$ merupakan dosis yang paling efektif sebagi analgetika.

\section{Saran}

1. Perlu dilakukan penelitian lebih lanjut tentang fraksi etanol daun lidah buaya apabila akan dibuat formulasi sediaan obat sehingga tetap berefek sebagai analgetika.

2. Disarankan pada peneliti selanjutnya untuk mengisolasi senyawa apa saja yang berkhasiat sebagai analgetika.

\section{UCAPAN TERIMAKASIH}

Terima kasih kepada Laboratorium Farmakologi Universitas Tulang Bawang Lampung yang telah membantu menyelesaikan penelitian ini. bahan uji. Dari hasil penelitian ini terlihat bahwa tidak semua tikus menunjukkan respon yang sama walaupun dalam satu kelompok perlakuan, hal ini dapat terjadi karena banyak faktor. Salah satu faktor yang diduga dapat mempengaruhi hal tersebut yaitu laju dan metabolisme obat yang berbeda dari setiap tikus adapun faktor-faktor yang mempengaruhi laju dan metabolisme obat yaitu penyakit, makanan, lingkungan dan faktor lain yang mungkin dikarenakan berbedanya intensitas rangsangan nyeri yang dapat ditahan oleh masing-masing individu [4].

\section{DAFTAR PUSTAKA}

[1] Christian A. Sewta, Christi Mambo, Jane Wuisan. 2015. Uji Efek Ekstrak Daun Lidah Buaya (Aloe vera L.) Terhadap Penyembuhan Luka Insisi Kulit Kelinci (Oryctolagus cuniculus). Jurnal eBiomedik (eBm). 3(1): 454

[2] Tjahajani A, Widurini. 2011. Aloe vera leaf anti Inflamation's activity speeds up the healing proccess of oral mucosa ulceration. Journal of Dentistry Indonesia. 18(1): 17-20.

[3] Cicilia Bertha Uli Lumban Gaol, Widdhi Bodhi, Widya Astuti Lolo. 2016. Uji Efek Analgetika Ekstrak Etanol Daun Lidah Buaya (Aloe vera L.) Pada Tikus Putih Jantan Galur Wistar (Rattus norvegicus). Jurnal IImiah Farmasi. 5(1): 8-14.

[4] Angelia Tudang, Jane Wuisan, Johanis A.Najoan W. 2013. Uji Efek Analgetik Ekstrak Daun Picisan (Polypodium nummulariifolium Mett.) Pada Mencit Swiss (Mus musculus). Jurnal e-biomedik (ebm). 1(2): 779-784

[5] Tjay, T. H,. Rahardja, K, 2002. Obat-obat Penting Khasiat dan Penggunaannya Edisi 5. Jakarta: PT Elex Medika Computindo. 
[6] Price, S. A., Wilson I. M. 2006. Patofisiologi Konsep Klinis Prosesproses Penyakit Edisi 6. Jakarta: EGC.

[7] Satyanegara, M.D, (1978). Teori dan Terapi Nyeri. Jakarta: Pantja Simpati.

[8] Heru sasongko, sugiyarto, yeni farida, nur rohman efendi, diah pratiwi, ahmad dwi setyawan, tentri widiyani. 2016. Aktivitas Analgesik Ekstrak Etanol Daun Karika (Carica pulbescens) Secara In Vitro. Journal of Pharmaceutical Science and Clinical Research. 01: 83-89.

[9] Dirjen POM. 2008. Farmakope Herbal Indonesia. Edisi I. Jakarta:
Departemen Kesehatan Republik Indonesia.

[10] Saifudin A. 2014. Senyawa Alam Metabolit Sekunder Teori, Konsep dan Teknik Pemurnian. Edisi I. Yogyakarta: DEEPUBLISH;

[11] Patel. J.M., 2008. A Review of Potential Health Benefit of Flavonoid, Lethbrige Undergraduate Research Journal. 3(2): 1-5. 